\title{
Recent advances in tissue-engineered corneal regeneration
}

\section{Eun Young Kim"), Jeong Eun Song'), Chan Hum Park²), Choun-Ki Joo ${ }^{3)}$ and Gilson Khang ${ }^{1, *)}$}

${ }^{1)}$ Department of PolymerNano Science \& Technology, Department of BIN Fusion Technology and Polymer BIN Fusion Research Center, Chonbuk National University, Jeonju, Korea

${ }^{2}$ Department of Otorhinolaryngology-Head and Neck Surgery, Chuncheon Sacred Heart Hospital, College of Medicine, Hallym University, Gangwon, Korea

3) Department of Ophthalmology and Visual Science, College of Medicine, The Catholic University of Korea, Gangnam St. Mary Hospital, Seoul, Korea

There are many dystrophies related corneal endothelium resulting in edema, loss of transparency and blindness, finally. Currently, transplantation is only surgical treatment for patients with these corneal endothelial dystrophies, however, the limitation of transplantation is the absolute deficiency of donor cornea. Very recently, to overcome this issue of limited supply of donor cornea, regenerative medicine including stem cell therapy and tissue engineering has been widely attempted and success for human clinical trial.

In this review, recent advances for the regeneration of corneal endothelial cell (CEnC) as (1)isolation and culture methods of CEnC for the somatic cell source, (2)stem cell source for CEnC as embryonic, induce pluripotent stem cell (iPS) and adult stem cell, (3)tissue engineering techniques as cell sheet engineering and development of scaffold materials and finally (4)the application of silk as a biomaterial for cornea by our laboratory have been introduced.

Rec.12/3/2013, Acc.1/7/2014, pp4-14

\footnotetext{
* Correspondence should be addressed to:

Gilson Khang, Department of PolymerNano Science \& Technology, Department of BIN Fusion Technology and Polymer BIN Fusion Research Center, Chonbuk National University, 567 Baekje-daero, Deokjin, Jeonju, 561-756 Korea. Phone: +82-63270-2355, Fax: +82-63-270-2341, E-mail: gskhang@jbnu.ac.kr
}

Key words biomaterials, cornea dystrophy, regenerative medicine, scaffolds, stem cell, tissue engineering

\section{Introduction}

Corneal endothelium is a monolayer of hexagonal cells and helps maintain corneal transparency via its barrier ${ }^{1,2)}$.
Corneal endothelial cells (CEnCs) have limited proliferative capacity in vivo ${ }^{1)}$ and do not replicate after severe injury or diseases losing significant number of normal CEnCs 
in human ${ }^{3)}$.

There are many dystrophies related corneal endothelium as Fuchs' dystrophy, posterior polymorphous corneal dystrophy, congenital hereditary endothelial dystrophy, X-linked endothelial dystrophy, and so on resulting in edema, loss of transparency and blindness, finally, 5). Currently, transplantation is only surgical treatment for patients with these corneal endothelial dystrophies ${ }^{2,6}$. However, the availability of donor cornea has been limited ${ }^{6}$. To overcome this issue of limited supply of donor cornea, CEnCs sheet with in vitro cultured $\mathrm{CEnCs}$ and regenerating bioengineered constructs using various matrices like denuded Descemet's membrane, decellularized stroma, amniotic membrane, collagen matrix, gelatin carriers and chitosan-based membranes have been attempted $\left.{ }^{7}, 8\right)$.

Being a biomaterial is a crucial factor for construction of artificial corneal equilibrium in tissue engineering because it can serve as a supporter and a microenvironment, which helps to regulate signals and control cellular regulations ${ }^{9}$. In addition, incorporating physical, chemical, and biological conditions to guide cells into functional tissues via cell migration, adhesion, and differentiation is important in this field $^{10,11)}$. The scaffolds prepared from many biomaterials should serve as cell carriers or supporters. In addition, they should have specificity for each applied tissue. In case of cornea endothelium, prepared scaffolds should process characteristics like transparency, permeability, proper curvature and flexibility as well as general properties of biomaterials like biocompatibility, non-cytotoxicity, proper biodegradability ${ }^{3)}$.

In this review, recent advances for the regeneration of CEnC as (1)isolation and culture methods of $\mathrm{CEnC}$ for the somatic cell source, (2)stem cell source for CEnC as embryonic, induce pluripotent stem cell (iPS) and adult stem cell, (3)tissue engineering techniques as cell sheet engineering and development of scaffold materials and finally (4)the application of silk as a biomaterial for cornea by our laboratory have been introduced.

\section{Isolation and optimization of culture methods for CEnC}

The monolayer of cells forming the human CEnCs (hCEnCs) is prerequisite to the maintenance of corneal transparency and is not known to regenerate in vivo. With advances in understanding CEnCs biology recently, it is now possible to cultivate hCEnCs in vitro, thus providing new opportunities to develop novel tissue-engineered hCEnCs ${ }^{12}$. In order to explore and optimize a proper culture system for hCEnCs, including the methods of primary culture, passage and cryopreservation, fresh fetal corneas were explanted to propagate primary corneal endothelial cells. Yans et al., cultured hCEnCs in DMEM/F-12 supplemented with $10 \%$ fetal bovine serum (FBS) in the absence or presence of the extracts from bovine CEnCs (bCEnCs). The passage and cryopreservation of hCEnCs were optimized adult corneal endothelial cells for the somatic cell source ${ }^{13)}$.

The evaluation of hCEnCs sourcing with various isolation methods, including enzymatic digestion, culture medium components, and adhesive proteins has been carried out by Choi et al. hCEnCs were obtained from corneas obtained from various aged donors after endothelial keratoplasty ${ }^{14)}$. Under a dissection microscope, the Descemet's membrane, including the attached corneal endothelium was stripped from the stroma and the cells were isolated and expanded by explant culture or by enzymatic digestion with enzymes such as collagenase II, dispase, or trypsin. In order to improve the initial cell attachment, tissue culture plates were coated with collagen IV, fibronectin, or fibronectin-collagen combination coating mix (FNC) before cell plating. We were able to successfully hCEnCs from $32 \%(86 / 269)$ of donor corneas ${ }^{14}$. Donor age and isolation method influenced the characteristics of the resulting in vitro hCEnCs culture. Under all conditions tested, FNC-coated plates showed higher quality cultures than the other coatings tested ${ }^{14)}$. These results suggested that donor age and hCEnCs isolation methodology are the two factors that most directly affect the quality of the resulting hCEnCs culture in vitro. These factors should guide the methodological development for the clinical expansion of hCEnCs for the generation of bioengineered neo-corneas ${ }^{14)}$.

Phe et al. have been investigated the density-dependent growth of hCEnCs isolated from paired donor corneas and to elucidate an optimal seeding density for their extended expansion in vitro whilst maintaining their unique cellular morphology. They proposed a seeding density of not less than 10,000 cells $/ \mathrm{cm}^{2}$ for regular passage of primary $\mathrm{hCEnCs}{ }^{15}$. Joyce reviewed the effect of donor age and endothelial topography on relative proliferative capacity of $\mathrm{hCEnCs}$, as well as explored the role of nuclear oxidative DNA damage in decreasing the relative proliferative ca- 
Special Issue (Review Article) Regeneration of cornea by regenerative medicine

pacity of hCEnCs. Potential new research directions has been discussed that could take advantage of and/or improve the proliferative capacity of these physiologically important cells in order to develop new treatments to restore corneal clarity ${ }^{1}$.

To evaluate the interaction of hCEnCs with ECM proteins with the ultimate goal to improve cell proliferation and function in vitro, cells were seeded on ECM-coated tissue culture dishes, including collagen type I (COL I), collagen type IV (COL IV), fibronectin (FN), FNC coating mix (FNC) and laminin $(\mathrm{LM})^{16)}$. Cell adhesion and proliferation of hCEnCs on each substratum and expression of hCEnCs markers were studied. hCEnCs plated on the COL I, COL IV, FN and FNC-coated plates had enhanced cell adhesion initially; the number for COL I, COL IV, FN and FNC was significantly higher than the control $(p<0.05)^{16)}$. In addition, cells grown on ECM protein-coated dishes showed more compact cellular morphology and hCEnCs marker expression compared to cells seeded on uncoated dishes ${ }^{16)}$. The effect of growth factors as hepatocyte growth factor (HGF), epidermal growth factor (EGF), transforming growth factor- $\beta$ (TGF- $\beta$ ) or TGF- $\beta_{1}$ on the biological response in bovine CEnCs in culture has been studied ${ }^{17}$. The size of the increased area of the culture on type IV collagen plus HGF was the largest of all the combinations of ECMs and growth factors. The responses of component cells in the increased area consisted of cellular hypertrophy, proliferation, migration and giant cell formation. The treatment with type IV collagen plus HGF clearly promoted all the above responses ${ }^{17}$.

Okumura et al. had been studied for the establishment an optimum condition for the cultivation of CEnCs by the use of SB431542, a selective inhibitor of TGF- $\beta$ receptor ${ }^{18)}$ and the selective Rho kinase (ROCK) inhibitor Y-27632 ${ }^{19}$. These findings show that SB431542 and ROCK inhibitor Y-27632 eye drops promote corneal endothelial wound healing in a primate animal model and suggest the possibility of Y-27632 as a novel therapeutic modality for certain forms of corneal endothelial dysfunction ${ }^{20}$.

\section{Stem cell source for $\mathrm{CEnC}$ as embryonic, iPS and adult stem cell}

Very recently, the development on the differentiation of various stem cells to $\mathrm{CEnCs}$ are intensively carried out since primary cell source might be have some ultimate limitation as proliferation, gain of enough cell number and so on.
Tan et al. has been carried out the mixed-culture with hiPSCs and rCEnCs to investigate the morphology and protein expression and to provide the experimental basis and the mechanism of iPSC differentiation into rCEnCs ${ }^{211}$. This work showed iPSCs morphologically change to endothelial-like cells after mixed culture with rCEnCs and express the marker protein AQP1 of rCEnCs at the same time $^{211}$.

Ostrowska et al. reported a differentiation protocol that yields corneal orbs from human embryonic stem cells as well as from human pluripotent parthenogenetic stem cells, and therefore can be manufactured free of transmissible pathogens ${ }^{22}$. The differentiated corneal product is layered and anatomically similar to normal human cornea, expresses appropriate corneal markers at the mRNA and protein (and secreted protein) levels, and is permeable to topical ophthalmic drugs ${ }^{22)}$. This method proposed showed positive results.

Nakahara et al. has been confirmed that CEnCs expansion was promoted by human bone marrow mesenchymal stem cell (BMSC)-derived conditioned medium (BMSC$\mathrm{CM})^{23)}$. When hCEnCs were maintained in the presence of BMSC-CM, cell morphology assumed a hexagonal shape similar to hCEnCs in vivo, as opposed to the irregular cell shape observed in control cultures in the absence of BMSC$\mathrm{CM}^{23)}$. This work indicates that MSC-CM not only stimulates the proliferation of hCEnCs by regulating the G1 proteins of the cell cycle but also maintains the characteristic differentiated phenotypes necessary for the endothelial functions ${ }^{23)}$.

Joyce et al. have been tested the feasibility of altering the phenotype of umbilical cord blood mesenchymal stem cells (UCBMSCs) toward that of hCEnCs and to determine whether UCBMSCs can "home" to sites of hCEnCs injury using an ex vivo corneal wound model24). Results indicate that UCBMSCs are able to "home" to areas of injured corneal endothelium and that the phenotype of UCBMSCs can be altered toward that of hCEnCs-like cells ${ }^{24)}$.

Ju et al. have been investigated the feasibility of inducing rat neural crest cells (NCC) to differentiate to functional CEnCs-like cells in vitro by the induction with adult CEnCsderived conditioned medium ${ }^{25}$. Spindle-like NCC turned to polygonal CEnCs-like after induction and expressed $\mathrm{N}$ cadherin, FoxC1, Pitx2, zonula occludens-1 and sodiumpotassium pump $\mathrm{Na}^{+} / \mathrm{K}^{+}$ATPase at 2 months in vivo. They 


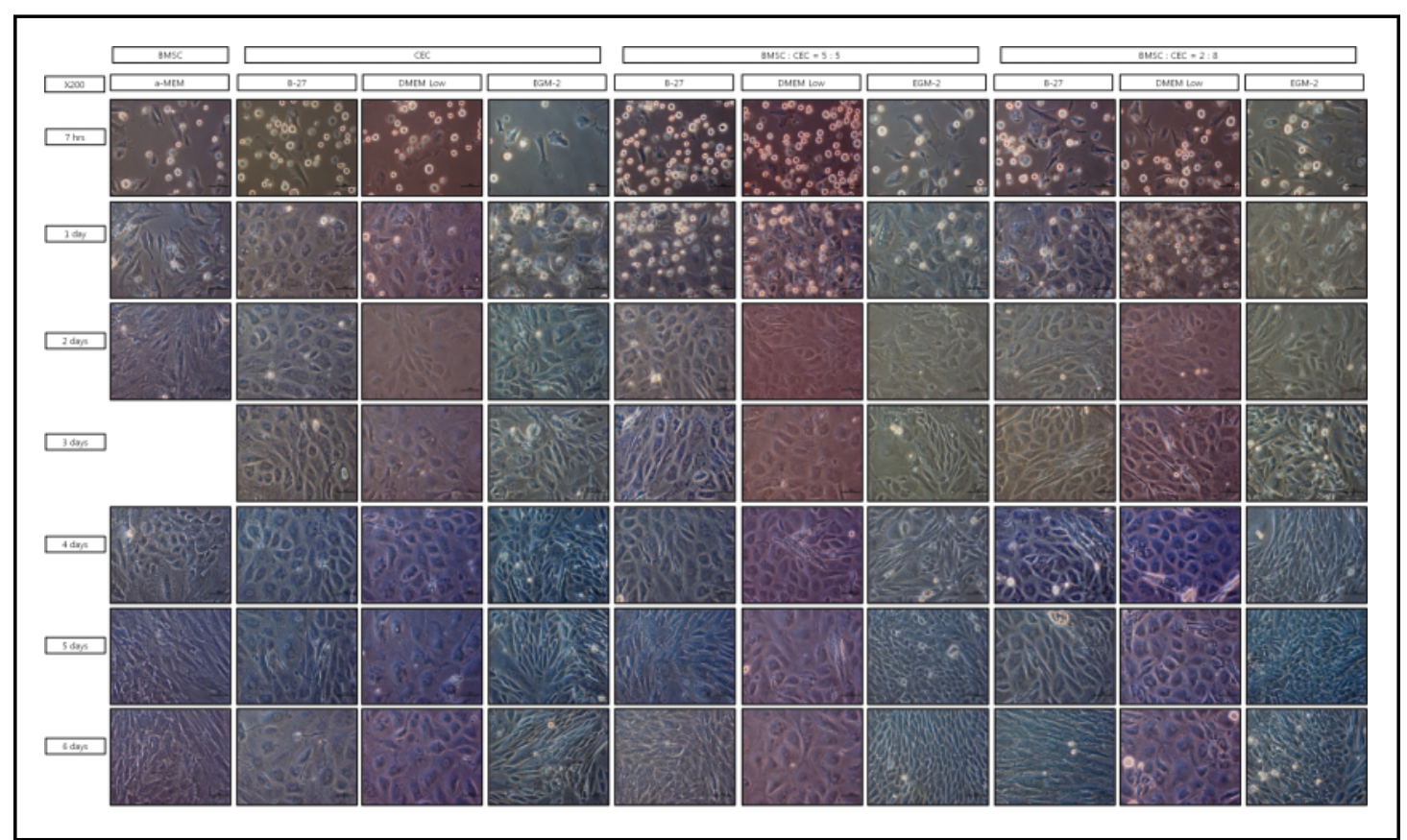

Fig.1 Morphological changes in derived-CEnCs at from 7 hrs to 6 days after direct coculture on each condition (Magnification x200) [Adapted from Ref. ${ }^{28)}$; Copyright permission from World Scientific Publications].

concluded that CEnC-like cells derived from NCCs displayed characters of native CEnCs, and the induction protocol provides guidance for future human $\mathrm{CEnCs}$ induction from NCC ${ }^{25}$.

Hatou et al. reported for the functional corneal endothelium derived from corneal stroma stem cells of neural crest origin by retinoic acid and $\mathrm{Wnt} / \beta$-catenin signaling. The induction of functional tissue-engineered corneal endothelium from mouse and human cornea-derived precursors had been carried out. This protocol enables efficient production of corneal endothelium from corneal stromal stem cells by direct induction ${ }^{26)}$.

Shao et al. had been explored the feasibility of inducing bone marrow-derived endothelial progenitor cells (BEPC) to differentiate into CEnCs by cocultured with CEnCs for 10 days in a transwell system with conditioned medium from $\mathrm{CEnCs}^{27}$. The induced BEPC resembled CEnC in polygonal shape, expressing aquaporin-1, tightly opposed cell junctions, and neuron-specific enolase. Twenty-eight days after surgery, the transparency gradually returned to the corneas transplanted with the induced BEPC on PCACM ${ }^{27}$.

To compensate insufficient number of CEnCs and to apply derived corneal endothelial like cells (CEn-like cells) on proper scaffolds for reconstruction of corneal endothelium, we are trying to the differentiation of BMSC to CEn-like cells with direct and indirect co-culture methods in our laboratory. Figure $1^{28)}$ showed the morphological changes from BMSC to CEn-like cells at from 7 hrs to 6 days with different medium conditions and direct co-culture method. Morphological changes were confirmed that the ratio of CEnCs and the supplements for culture are more increased, the differentiated morphology becomes more similar to $\mathrm{CEnCs}^{28)}$.

\section{Tissue engineering techniques and de- velopment of scaffold materials}

\section{1)Cell Sheet Engineering}

Recently, one of the promising and most successful tissue engineered methods for the regeneration of CEnC might be a "Cell Sheet Engineering" using the temperature-responsive polymer developed by Okano Group ${ }^{29}$. Core technology was the changes of the temperature which allows regulation of the attachment or detachment of living cells on the culture surfaces grafted with the temperatureresponsive polymer "poly(N-isopropylacrylamide)". This technology provides to construct bioengineered sheetlike tissues, termed "cell sheets", without the need of using biodegradable scaffolds and protease treatments that are traditionally used ${ }^{29}$. Furthermore, this technology has successfully performed the clinical application for the re- 
construction of ocular surfaces through the transplantation of our carrier-free corneal epithelial cell sheets over the world ${ }^{30-32)}$. We hope cell sheet engineering can lunch on the market soon.

Teichmann et al. reports a novel thermo-responsive carrier based on simultaneous electron beam immobilization and crosslinking of poly(vinyl methyl ether) (PVME) on polymeric surfaces, which allows one to adjust layer thickness, stiffness, switching amplitude and functionalization with bioactive molecules to meet cell type specific requirements instead of poly( $\mathrm{N}$-isopropylacrylamide $)^{33)}$.

\section{2)Scaffold Biomaterials for Corneal Reconstruction}

In recent years decellularized corneas have been under investigation as an alternative scaffold source for use in engineering cornea. Several strategies for lysing cells and removing cellular material from corneas are introduced ${ }^{34)}$. Choi et al. had been established hCEnC isolation and culture protocols and to investigate the feasibility of bioengineering corneal tissue constructs by seeding the cells on decellularized human corneal stroma ${ }^{35)}$. Donor corneal stromas were cut to $120-200 \mu \mathrm{m}$ thickness slices using a microtome and then decellularized. To engineer neo-corneas, $130 \mathrm{hCEnC} / \mathrm{mm}^{2}$ were seeded on decellularized human corneal stromas. Seeded cells retain expression of the functional markers $\mathrm{Na}^{+} / \mathrm{K}^{+}$-ATPase and $\mathrm{ZO}-1$ and constructs have biomechanical properties similar to those of normal corneas ${ }^{35)}$. These results indicate that construction of neo-corneas, using hCEnC derived from discarded donor corneas and decellularized thin-layer corneal stromas, may create a new source of high quality corneal tissue for transplantation ${ }^{35)}$. Ju et al. has been carried out the application of decellularized porcine corneas with sodium dodecyl sulphate (SDS) solution and then hCEnCs B4G12 were cultured $^{36)}$. This work showed that B4G12 cells served as a good model for native corneal endothelial cells in vivo. Shimmura et al. had been tried the transplantation of corneal endothelium with Descemet's membrane using a hyroxyethyl methacrylate polymer as a carrier ${ }^{37)}$. Sano et al. was conducted to examine the feasibility of using amniotic membrane as a carrier for the regeneration of corneal endothelium $^{38)}$. The results of these two trials showed that the cell density and morphology of hCEnCs on cell carriers were similar to those of normal corneas, and hCEnCs on cell carriers were functional in vivo ${ }^{38)}$.

Chen et al. had been investigated the biocompatibility of collagen-chitosan-sodium hyaluronate (Col-Chi-NaHA) complexes and cornea tissue, and the feasibility of ColChi-NaHA complexes as substrates for cultivating rabbit corneal cells ${ }^{39)}$. Results showed that these hybrid complexes had good biocompatibility with cornea. Ambrose et al. had been evaluated the potential suitability of collagen Vitrigel (CV) membrane as a substrate for the separate reconstruction of the three main cellular layers of the cornea ${ }^{40)}$. Limbal explants, keratocytes, and endothelial cells were cultured on transparent membranes made of type I collagen. Levis et al. had been described the first use of plastic compressed collagen as a highly effective, novel carrier for hCEnCs ${ }^{41)}$. Mimura et al. had been evaluated the function of cultured hCEnCs in vivo and the feasibility of hCEnCs transplantation with a collagen sheet as the substitute carrier of hCEnCs ${ }^{42}$. These works reported that a collagen sheet as a cell carrier can retain their function of corneal dehydration in vivo model and suggest the feasibility of transplantation for corneal endothelium dysfunction using cultured hCEnCs with a collagen sheet ${ }^{42)}$.

Tabata group suggested a gelatin hydrogel as hCEnCs carrier. The gelatin hydrogel sheets displayed greater transparency, elastic modulus, and albumin permeability compared to those of atelocollagen sheets. hCEnCs on gelatin hydrogel sheets showed normal expression levels of ZO-1, $\mathrm{Na}^{+} / \mathrm{K}^{+}$-ATPase, and $\mathrm{N}$-cadherin ${ }^{43)}$. Lai et al. suggested a crosslinked porous gelatin hydrogels as cell sheet carriers for intraocular delivery fabricated by a simple stirring process combined with freeze-drying method to improve the fragility of bioengineered hCEnCs monolayers ${ }^{44)}$. These carriers are beneficial to the in vitro cultivation of CEnCs without limiting proliferation and changing expression of ion channel and pump genes such as ATP1A1, VDAC2, and AQP144). In vivo studies by analyzing the rCEnC morphology and count also demonstrate that the implanted gelatin discs with the highest solid content may cause unfavorable tissue-material interactions ${ }^{44)}$. Composite electrospun gelatin fiber-alginate gel scaffolds for mechanically robust tissue engineered cornea have been suggested by Tonsomboon to improve poor mechanical performance of hydrogel ${ }^{45)}$. Also, fibrin-agarose hydrogel were suggested for tissue engineered cornea by Alaminos ${ }^{46}$. Acellularized/decalcified fish scales-derived collagen scaffolds with highly centrally oriented micropatterned structure were newly developed for corneal regeneration ${ }^{47)}$. Chitosan/polycaprolactone blends ${ }^{48)}$, in situ formed biode- 
Special Issue (Review Article) Regeneration of cornea by regenerative medicine

Table 1 Sericin contents of Bombyx mori silk cocoons and fabricated LSS and HSS ${ }^{3)}$

\begin{tabular}{|c|c|c|c|c|c|c|c|c|c|}
\hline & \multicolumn{9}{|c|}{ Weight (unit : grams) } \\
\hline & \multicolumn{4}{|c|}{ Before Degumming } & \multirow[b]{2}{*}{$\begin{array}{c}\text { Boiling } \\
\text { time }\end{array}$} & \multicolumn{4}{|c|}{ After Degumming } \\
\hline & $\begin{array}{c}\text { Silk } \\
\text { Coccons }\end{array}$ & $\begin{array}{c}\text { Silk } \\
\text { Fibroin }\end{array}$ & $\begin{array}{l}\text { Silk } \\
\text { Sericin }\end{array}$ & $\begin{array}{l}\text { Ratio } \\
\text { of } \\
\text { Sericin }\end{array}$ & & $\begin{array}{c}\text { Silk } \\
\text { Cocoons }\end{array}$ & $\begin{array}{c}\text { Silk } \\
\text { Fibroin }\end{array}$ & $\begin{array}{c}\text { Silk } \\
\text { Sericin }\end{array}$ & $\begin{array}{c}\text { Ratio } \\
\text { of } \\
\text { Sericin }\end{array}$ \\
\hline LSS & & & & & $1 \mathrm{hr}$ & 40 & 37.5 & 2.5 & $6.25 \%$ \\
\hline HSS & & & & & $30 \mathrm{~min}$ & 41.59 & 37.5 & 4.09 & $9.83 \%$ \\
\hline
\end{tabular}

gradable hydrogel based on a watersoluble derivative of chitosan, hydroxypropyl chitosan, and sodium alginate dialdehyde ${ }^{49}$ ), ultrathin chitosan - poly(ethylene glycol) hydrogel ${ }^{50)}$, the synthetic biodegradable polyesters, poly $(\mathrm{L}-$ lactic) (PLLA) and poly(DL-lactic-co-glycolic acid) (85:15, PLGA ${ }^{51)}$ were also applied for the scaffold biomaterials for the reconstruction of cornea.

\section{3)Silk for Corneal Reconstruction}

Using silk as a biomaterial for cornea and other organs and tissues becomes a possible effort in tissue engineering because silk has been used as a suture for centuries ${ }^{52)}$. Silk cocoon from Bombyx mori (B. mori) contains two main types of proteins: fibroin and sericin ${ }^{53)}$. Fibroin, which makes up $75 \%$ of the protein content of silk cocoon, is an insoluble protein composed of up to $90 \%$ glycine, alanine and serine. It consists of a heavy chain $(325,000 \mathrm{Da})$ and a light chain $(25,000 \mathrm{Da})$ which has the primary structure of fibroin consisting of repeatable sequences of (Gly-Ser-Gly-Ala-GlyAla) $n$. It has been proved that fibroin has non-immunogenic response upon in vivo implantation, controllable degradation rate, excellent mechanical properties and good oxygen/water vapor permeability ${ }^{3,10,54-59)}$. In addition, it supports the proliferation and attachment of human limbal epithelial stem cell and murine fibroblast, and has various applications such as wound cover, enzyme immobilization membrane, cell culture medium, artificial skin, and soft contact lenses ${ }^{60-63)}$. Many researchers demonstrated that two dimensional silk fibroin films provide good biocompatibil-

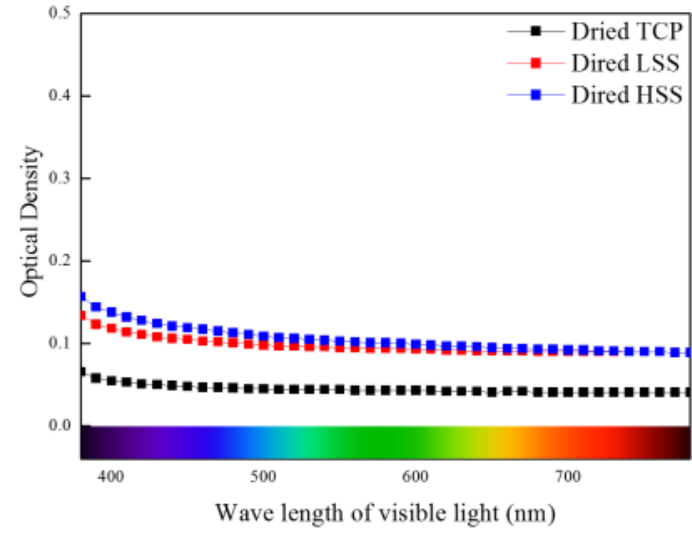

(b)

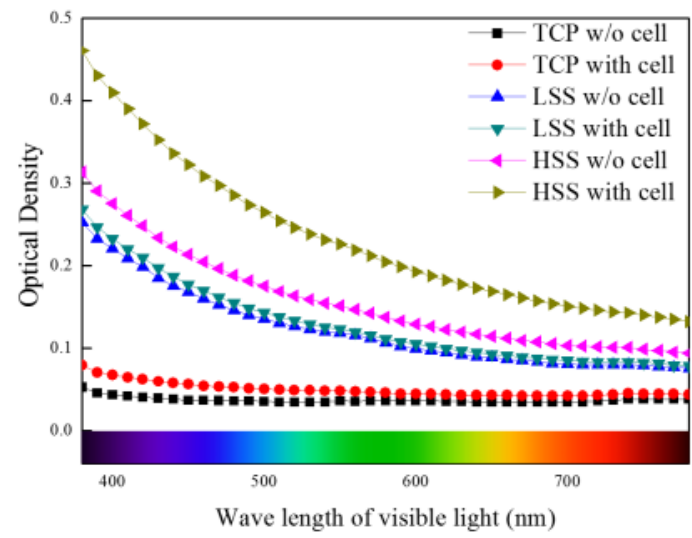

Fig.2 Optical transparency patterns of silk fibroin films in the visible range. Dried samples were taken from Figure 1 [Adapted from Ref. ${ }^{3)}$; Copyright permission from Springer Publications].

ity $^{3,57,64,65)}$.

Sericin protein, which makes up the remaining $25 \%$ of silk, is composed of 18 amino acids arranged in three different polypeptides of 400,250 and $150 \mathrm{kDa}^{66)}$. The hydrophilic sericin protein has a strong polar side chain and is used to produce biodegradable materials with various advantages such as anti-coagulating agent, anti-wrinkle agent and anti-oxidant ${ }^{67)}$. Recently, it has been reported that sericin prevents apoptosis, suppresses tumor promotion, enhances proliferation of mammalian cells and attachment of human fibroblast, and is used as a supplement in cell culture media ${ }^{68,69)}$.

We fabricated two types of silk fibroin films by treating them at different boiling time as $9.83 \%$ of sericin (high sericin silk, HSS) and $6.25 \%$ of sericin (low sericin silk, LSS) as listed in Table 1. LSS was boiled for 1 hour, while HSS was boiled $30 \mathrm{~min}$ to remove sericin ${ }^{3)}$. 


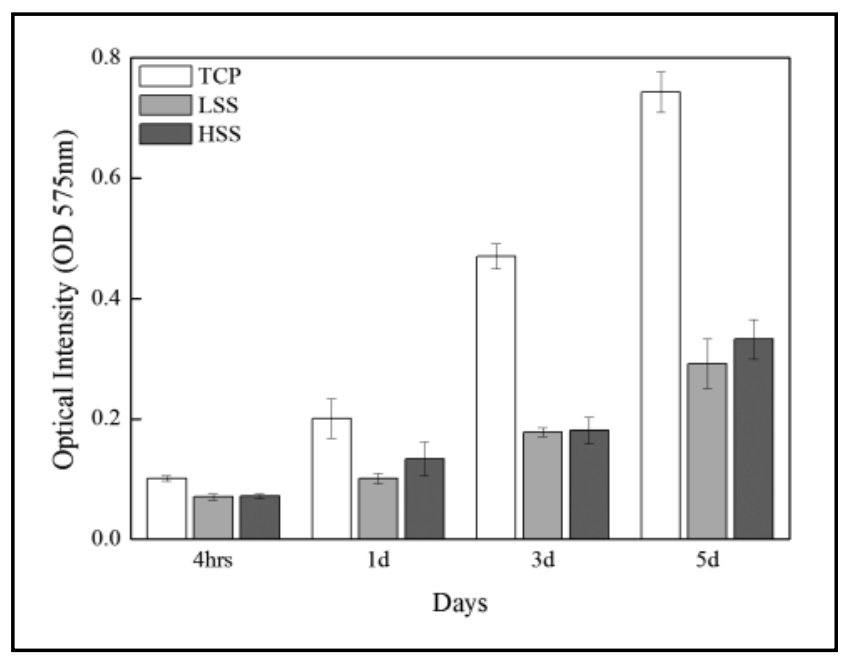

Fig.3 Cell proliferation measurement of using the MTT assay TCP was used as a positive control. LSS and HSS show a significant difference in optical intensity $\left({ }^{*} p<0.01\right) 5$ days post-seeding compared to TCP [Adapted from Ref. ${ }^{3)}$; Copyright permission from Springer Publications].

Figure $2^{3)}$ showed the difference between dried LSS and HSS and the transparency of dried HSS was lower than dried LSS. Study about sericin included films showed that by increasing sericin content, turbidity of films increase. As sericin content of HSS is higher than LSS, we concluded that fabricated HSS's turbidity is little higher than LSS. The opacity of wet films in culture medium increased when compared to dried films ranges between $380 \mathrm{~nm}$ and $550 \mathrm{~nm}$. Furthermore, the opacity of the films cultured rCEnCs was higher than wet film without rCEnCs in culture medium. The increase in opacity was caused by light scattering effect on the CEnCs. Nonetheless, object recognition through wet films was still considered possible ${ }^{3)}$.

Figure $3^{3)}$ is the proliferation result of rCEnCs by MTT at $4 \mathrm{hrs}, 1,3$, and 5 days after seeding on LSS and HSS as experiment groups and TCP as a control group. Four hrs after seeding, optical intensity of rCEnCs on LSS and HSS shows no difference between LSS and HSS. Even though here is nothing to show the morphologic images at confluent, their morphology on TCP, LSS and HSS are polygonal and formed single layer on each conditions. As time goes by, both groups were proliferated up to confluent stage but still have no difference among them. However, rCEnCs on HSS has more proliferation compared with rCEnCs on LSS cultures up to 5 days $^{3)}$. Successive works have been carried out that fibroin's strength, structural versatility and poten- tial for modification, combined with the relative simplicity of associated manufacturing processes, make fibroin a worthy candidate for further exploration ${ }^{70,71)}$.

\section{Conclusion and Future Prospective}

Regenerative medicine including tissue engineering and stem cell therapy shows tremendous potential for a corneal regeneration. Also, many successful results have been reported the potential for regenerating eye as joint on the stem cell and scaffold biomaterials from polymers, ceramic, metal, composites and its hybrids. As we mentioned earlier, "cell sheet engineering" also emerged next generation of corneal dysfunction treatment based on the success of human clinical trial.

For the success of tissue engineering techniques, the prerequisite physicochemical properties of scaffolds are (i) to support and deliver for cells, (ii) to induce, differentiate and conduit tissue growth, (iii) to target cell-adhesion substrate, (iv) to stimulate cellular response, (v) wound healing barrier, (vi) biocompatible and biodegradable, (vii) relatively easy processability and malleability into desired shapes, (viii) highly porous with large surface/volume, (ix) mechanical strength and dimensional stability, (x) sterilizability, (xi) do not induce inflammatory reaction and fibrotic capsule and so on ${ }^{72-77)}$.

Also, stem cell must emerge more important cell source since primary cell of CEnCs has a limitation of proliferation and dedifferentiation itself. We must need the development of differentiation methods from stem cell source using small molecule, protein, peptide and so on. From this point of view, the appropriate combination of the cells and bioactive scaffolds has attempted to regenerate for corneal. In order to achieve this goal, the novel hybrid scaffold biomaterials, the novel differentiation methods of stem cell to CEnCs must be developed.

\section{Acknowledgments and Source of Funding}

This work was supported by the BK-21 PLUS and Bio \& Medical Technology Development Program of the NRF (NRF2012M3A9C6050204) and Bio-industry Technology Development Program (112007-05-2-SB010), Ministry for Food, Agriculture, Forestry and Fisheries, Republic of Korea.

\section{Conflict of Interest}

None 
Special Issue (Review Article) Regeneration of cornea by regenerative medicine

\section{References}

1) Joyce NC: Proliferative capacity of corneal endothelial cells. Exp Eye Res. 2012; 95: 16-23.

2) Mimura $T$, Yokoo $S$, Yamagami $S$ : Tissue engineering of corneal endothelium. J Funct Biomater. 2012; 3: 726744.

3) Yoon H, Kim EY, Kim H, Park CH, Joo CK, Khang G: Fabrication of transparent silk fibroin film for the regeneration of corneal endothelial cells; Preliminary study. Macromol Res. 2014; 22. doi: 10.1007/s13233014-2037-6.

4) Aldave AJ, Sonmez B: Elucidating the molecular genetic basis of the corneal dystrophies: Are we there yet? Arch Ophthalmol. 2007; 125: 177-186.

5) Aldave AJ, Han J, Frausto RF: Genetics of the corneal endothelial dystrophies: An evidence-based review. Clin Genet. 2013; 84: 109-119.

6) Sabater AL, Guarnieri A, Espana EM, Li W, Prosper F, Moreno-Montanes J: Strategies of human corneal endothelial tissue regeneration. Regen Med. 2013; 8: 183195.

7) Zavala J, Jaime GRL, Barrientos CAR, Valdez-Garcia $\mathrm{J}$ : Corneal endothelium: developmental strategies for regeneration. Eye. 2013; 27: 579-588.

8) Joyce NC, Harris DL, Markov V, Zhang Z, Saitta B: Potential of human umbilical cord blood mesenchymal stem cells to heal damaged corneal endothelium. Mol Vis. 2012; 18: 547-564.

9) Wang $\mathrm{JH}$, Hung $\mathrm{CH}$, Young TH: Proliferation and differentiation of neural stem cells on lysine-alanine sequential polymer substrates. Biomaterials. 2006; 27 : 3441-3450.

10) Vepari C, Kaplan DL: Silk as a biomaterial. Prog Polym Sci. 2007; 32: 991-1007.

11) Kim TH, Ko JH, Kim SJ, Park YH: Implantable medical textiles. Intern J Tissue Regen. 2011; 2: 1-12.

12) Peh GS, Beuerman RW, Colman A, Tan DT, Mehta JS: Human corneal endothelial cell expansion for corneal endothelium transplantation: An overview, Transplantation. 2011; 91: 811-819.

13) Gao $Y$, Zhou $Q$, Qu M, Yang L, Wang $Y$, Shi W: In vitro culture of human fetal corneal endothelial cells. Graefes Arch Clin Exp Ophthalmol. 2011; 249: 663-669.

14)Choi JS, Kim EY, Kim MJ, Khan FA, Giegengack M, D'Agostino R Jr, Criswell T, Khang G, Soker S: Factors affecting successful isolation of human corneal en- dothelial cells for clinical use. Cell Transplant. 2013; doi: 10.3727/096368913X664559.

15) Peh GS, Toh KP, Ang HP, Seah XY, George BL, Mehta JS: Optimization of human corneal endothelial cell culture: density dependency of successful cultures in vitro, BMC Res Notes. 2013; 3: 176.

16)Choi JS, Kim EY, Kim MJ, Giegengack M, Khan FA, Khang G, Soker S: In vitro evaluation of the interactions between human corneal endothelial cells and extracellular matrix proteins. Biomed Mater. 2013; 8: 014108. doi: 10.1088/1748-6041/8/1/014108.

17) Mitsumoto $T$, Nishimura $T$, Toda $S$, Okinami $S$, Oono $\mathrm{S}$, Sugihara $\mathrm{H}$ : Combined effect of extracellular matrices and growth factors on bovine corneal endothelial cells in culture. Jpn J Ophthalmol. 2001; 45: 115-124.

18) Okumura N, Kay EP, Nakahara M, Hamuro J, Kinoshita $\mathrm{S}$, Koizumi N: Inhibition of TGF- $\beta$ signaling enables human corneal endothelial cell expansion in vitro for use in regenerative medicine. PLoS One. 2013; 8: e58000.

19) Okumura $N$, Koizumi $N$, Ueno $M$, Sakamoto $Y$, Takahashi H, Tsuchiya H, Hamuro J, Kinoshita S: ROCK inhibitor converts corneal endothelial cells into a phenotype capable of regenerating in vivo endothelial tissue. Am J Pathol. 2012; 181: 268-277.

20)Okumura N, Koizumi N, Kay EP, Ueno M, Sakamoto Y, Nakamura S, Hamuro J, Kinoshita S: The ROCK inhibitor eye drop accelerates corneal endothelium wound healing. Invest Ophthalmol Vis Sci. 2013; 54: 2439-2502.

21) Tan MH, Chen JS, Zhao ZY, Ding Y, Zhong JX, Dai $Y$, LI SY, Yang HZ: Mixed culture of human iPSCs with rabbit corneal endothelial cells induces differentiation of iPSCs. Chin J Physiol. 2012; 28: 1488-1493.

22) Ostrowska A, Cochran J, Agapova L, Buz'Zard A, Turovets N, Hammond J, Turovets I, Krishnakumar S, Semechkin A, Kelleher-Andersson J, Janus J, Csete M: Corneal spheres derived from human embryonic and human pluripotent parthenogenetic stem cells. J Stem Cell Res Ther. 2011; S2:006. doi:10.4172/21577633.S2-006.

23) Nakahara M, Okumura N, Kay EP, Hagiya M, Imagawa K, Hosoda Y, Kinoshita S, Koizumi N: Corneal endothelial expansion promoted by human bone marrow mesenchymal stem cell-derived conditioned medium. PLoS One. 2013; 8: e69009. 
24)Joyce NC, Harris DL, Markov V, Zhang Z, Saitta B: Potential of human umbilical cord blood mesenchymal stem cells to heal damaged corneal endothelium. Mol Vis. 2012; 18: 547-564.

25) Ju C, Zhang K, Wu X: Derivation of corneal endothelial cell-like cells from rat neural crest cells in vitro. PLoS One. 2012; 7: e42378.

26)Hatou S, YoshidaS, Higa K, Miyashita H, Inagaki E, Okano H, Tsubota K, Shimmura S: Functional corneal endothelium derived from corneal stroma stem cells of neural crest origin by retinoic acid and $\mathrm{Wnt} / \beta$-catenin signaling. Stem Cells Dev. 2013; 22: 828-839.

27) Shao $C$, Fu $Y$, Lu W, Fan $X$ : Bone marrow-derived endothelial progenitor cells: A promising therapeutic alternative for corneal endothelial dysfunction, Cells Tissues Organs. 2011; 193: 253-263.

28) Kim EY, Choi JS, Khang G, Soker S: Chap. S. Protocol of the differentiation of BMSC to corneal endothelial cells by direct and indirect co-culture, In: A manuals for differentiation of bone marrow derived stem cell to specific cell types, Edited by. Khang G, Shimizu T, $\mathrm{Ng} \mathrm{KW}$. World Scientific Publisher, Singapore, in press.

29) Terumasa U, Masayuki $Y$, Kohji N, Teruo O: Regenerative medicine of cornea by cell sheet engineering using temperature-responsive culture surfaces. Chin Sci Bull. 2013; 58: 4349-4356.

30) Sumide $T$, Nishida $K$, Yamato $M$, Ide $T$, Hayashida $Y$, Watanabe K, Yang J, Kohno C, Kikuchi A, Maeda N, Watanabe H, Okano T, Tano Y: Functional human corneal endothelial cell sheets harvested from temperature-responsive culture surfaces. FASEB J. 2006; 20: 392-394.

31) Ide $T$, Nishida $K$, Yamato $M$, Sumide $T$, Utsumi $M$, Nozaki T, Kikuchi A, Okano T, Tano Y: Structural characterization of bioengineered human corneal endothelial cell sheets fabricated on temperature-responsive culture dishes, Biomaterials. 2006; 27: 607-614.

32)Lai JY, Chen KH, Hsu WM, Hsiue GH, Lee YH: Bioengineered human corneal endothelium for transplantation, Arch Ophthalmol. 2006; 124: 1441-1448.

33) Teichmann J, Valtink M, Gramm S, Nitschke M, Werner $\mathrm{C}$, Funk RH, Engelmann K: Human corneal endothelial cell sheets for transplantation: Thermo-responsive cell culture carriers to meet cell-specific requirements. Acta Biomater. 2013; 9: 5031-5039.

34)Lynch AP, Ahearne M; Strategies for developing decellularized corneal scaffolds, Exp Eye Res. 2013; 108: $42-47$.

35)Choi JS, Williams JK, Greven M, Walter KA, Laber PW, Khang G, Soker S: Bioengineering endothelialized neocorneas using donor-derived corneal endothelial cells and decellularized corneal stroma. Biomaterials. 2010; 31: 6738-6745.

36) Ju C, Gao L, Wu X, Pang K: A human corneal endothelium equivalent constructed with acellular porcine corneal matrix. Indian J Med Res. 2012; 135: 887-894.

37) Shimmura $S$, Miyashita $H$, Konomi K, Shinozaki $N$, Taguchi T, Kobayashi H, Shimazaki J, Tanaka J, Tsubota K: Transplantation of corneal endothelium with Descemet's membrane using a hyroxyethyl methacrylate polymer as a carrier, $\mathrm{Br} \mathrm{J}$ Ophthalmol. 2005; 89: 134-137.

38) Ishino $Y$, Sano $Y$, Nakamura T, Connon CJ, Rigby H, Fullwood NJ, Kinoshita S: Amniotic membrane as a carrier for cultivated human corneal endothelial cell transplantation, Invest Ophthalmol Vis Sci. 2004; 45: 800-806.

39) Chen J, Li Q, Xu J, Huang Y, Ding Y, Deng H, Zhao S, Chen R: Study on biocompatibility of complexes of collagen-chitosan-sodium hyaluronate and cornea. Artif Organs. 2005; 29: 104-113.

40)Ambrose WM, Salahuddin A, So S, Ng S, Marquez SP, Takezawa T, Schein O, Elisseeff J: Collagen vitrigel membranes for the in vitro reconstruction of separate corneal epithelial, stromal, and endothelial cell layers, J Biomed Mater Res. Part B: Appl Biomater 2009; 90B: 818-831.

41) Levis HJ, Peh GS, Toh KP, Poh R, Shortt AJ, Drake RA, Mehta JS, Daniels JT: Plastic compressed collagen as a novel carrier for expanded human corneal endothelial cells for transplantation. PLoS ONE 2012; 7: e50993.

42) Mimura T, Yamagami S, Yokoo S, Usui T, Tanaka K, Hattori S, Irie S, Miyata K, Araie M, Amano S: Cultured human corneal endothelial cell transplantation with a collagen sheet in a rabbit model, Invest Ophthalmol Vis Sci. 2004; 45: 2992-2997.

43) Watanabe R, Hayashi R, Kimura $Y$, Tanaka $Y$, Kageyama T, Hara S, Tabata Y, Nishida K: A novel gelatin hydrogel carrier sheet for corneal endothelial transplantation, Tissue Eng. Part A. 2011; 17: 22132219. 
Special Issue (Review Article) Regeneration of cornea by regenerative medicine

44) Lai JY, Ma DHK, Lai MH, Li YT, Chang RJ; Characterization of cross-linked porous gelatin carriers and their interaction with corneal endothelium: Biopolymer concentration effect. PLoS ONE. 2013; 8: e54058.

45)Tonsomboon $\mathrm{K}$, Oyen $\mathrm{M}$ : Composite electrospun gelatin fiber-alginate gel scaffolds for mechanically robust tissue engineered cornea, J Mech Behav Biomed. 2013; 21: 185-194.

46) Alaminos M, Del Carmen Sanchez-Quevedo M, MunozAvila JI, Serrano D, Medialdea S, Carreras I, Campos A: Construction of a complete rabbit cornea substitute using a fibrin-agarose scaffold. Invest Ophthalmol Vis Sci. 2006; 47: 3311-3317.

47) Lin CC, Ritch R, Lin SM, Ni MH, Chang YC, Lu YL, Lai HJ, Lin FH: A new fish scale-derived scaffold for corneal regeneration. Eur Cell Mater. 2010; 19: 50-57.

48) Wang TJ, Wang IJ, Chen S, Yi-Hsin Chen, Tai-Horng Young: The phenotypic response of bovine corneal endothelial cells on chitosan/polycaprolactone blends, Colloids and Surfaces B: Biointerfaces. 2012; 90: 236243.

49) Liang $Y$, Liu W, Han B, Yang C, Ma Q, Song F, Bi Q: An in situ formed biodegradable hydrogel for reconstruction of the corneal endothelium. Colloids and Surfaces B: Biointerfaces. 2011; 82: 1-7.

50)Ozcelik B, Brown KD, Blencowe A, Daniell M, Stevens GW, Qiao GG: Ultrathin chitosan-poly(ethylene glycol) hydrogel films for corneal tissue engineering, Acta Biomater. 2013; 9: 6594-6605.

51) Hadlock T, Singh S, Vacanti JP, Maclaughlin B: Ocular cell monolayers cultured on biodegradable substrates. Tissue Eng. 1999; 5: 187-196.

52)Moy RL, Lee A, Zalka A: Commonly used suture materials in skin surgery. Am Fam Physician. 1991; 44: 21232128.

53)Kato N, Sato S, Yamanaka A, Yamada H, Fuwa N, Nomura M: Silk protein, sericin, inhibits lipid peroxidation and tyrosinase activity. Biosci Biotechnol Biochem. 1998; 62: 145-147.

54)Shao Z, Vollrath F: Surprising strength of silkworm silk. Nature. 2002; 418: 741.

55) Panilaitis B, Altman GH, Chen J, Jin HJ, Karageorgiou V, Kaplan DL: Macrophage responses to silk. Biomaterials. 2003; 24: 3079-3085.

56)Arai T, Freddi G, Innocenti R, Tsukada M: Biodegradation of Bombyx mori silk fibroin fibers and films. J
Appl Polym Sci. 2004; 91: 2383-2390.

57) Meinel L, Hofmann S, Karageorgiou V, Kirker-Head C, McCool J, Gronowicz G, Zichner L, Langer R, Vunjak-Novakovic G, Kaplan DL: The inflammatory responses to silk films in vitro and in vivo. Biomaterials. 2005; 26: 147-155.

58) Motta A, Fambri L, Migliaresi C, Regenerated silk fibroin films: Thermal and dynamic mechanical analysis. Macromol Chem Physic. 2002; 203: 1658-1665.

59)Minoura N, Tsukada M, Nagura: Physico-chemical properties of silk fibroin membrane as a biomaterial. Biomaterials. 1990; 11: 430-434.

60)Lawrence BD, Cronin-Golomb M, Georgakoudi I, Kaplan DL, Omenetto FG: Bioactive silk protein biomaterial systems for optical devices. Biomacromolecules. 2008; 9: 1214-1220.

61) Li M, Tao W, Kuga S, Nishiyama $Y$, Controlling molecular conformation of regenerated wild silk fibroin by aqueous ethanol treatment. Polym Advan Technol. 2003; 14: 694-698.

62) Lee OJ, Lee JM, Jin HJ, Park $\mathrm{CH}$, The pilot study for the development of the artificial dermis using silk fibroin. Intern J Tissue Regen. 2010; 1: 68-73.

63) Yamamoto M, Tabata Y. Protein Immobilization onto biomaterial surfaces to control cell behaviors for tissue regeneration. Intern J Tissue Regen. 2013; 4: 3640.

64)Altman GH, Diaz F, Jakuba C, Calabro T, Horan RL, Chen J, Lu H, Richmond J, Kaplan DL: Silk-based biomaterials. Biomaterials. 2003; 24: 401-416.

65)Wang Y, Rudym DD, Walsh A, Abrahamsen L, Kim HJ, Kim HS, Kirker-Head C, Kaplan DL: In vivo degradation of three-dimensional silk fibroin scaffolds. Biomaterials. 2008; 29: 3415-3428.

66) Nishida A, Naganuma $T$, Kanazawa $T$, Takashima $Y$, Yamada M, Okada $\mathrm{H}$ : The characterization of protein release from sericin film in the presence of an enzyme: towards fibroblast growth factor-2 delivery. Int J Pharm. 2011; 414: 193-202.

67)Kaewkorn W, Limpeanchob N, Tiyaboonchai W, Pongcharoen S, Sutheerawattananonda M: Effects of silk sericin on the proliferation and apoptosis of colon cancer cells. Biol Res. 2012; 45: 45-50.

68) Tsubouchi K, Igarashi $Y$, Takasu $Y$, Yamada H: Sericin enhances attachment of cultured human skin fibroblasts. Biosci Biotechnol Biochem. 2005; 69: 403- 
405.

69) Liu J, Lawrence BD, Liu A, Schwab IR, Oliveira LA, Rosenblatt MI: Silk fibroin as a biomaterial substrate for corneal epithelial cell sheet generation. Invest Ophthalmol Vis Sci. 2012; 53: 4130-4138.

70) Harkin DG, George KA, Madden PW, Schwab IR, Hutmacher DW, Chirila TV: Silk fibroin in ocular tissue reconstruction. Biomaterials. 2011; 32: 2445-2458.

71) Madden PW, Lai J, George KA, Giovenco T, Harkin DG, Chirila TV: Human corneal endothelial cell growth on a silk fibroin membrane. Biomaterials. 2011; 32 : 4076-4084.

72)Khang G, Kim MS, Lee HB: Introduction. In: A Mannual for the Fabrication of Tissue Engineered Scaffolds. World Scientific Pub, Singapore; 2008, pp1-12.

73) Khang G, Lee SJ, Kim MS, Lee HB: Biomaterials: Tissue-Engineering and Scaffolds. In: Encyclopedia of
Medical Devices and Instrumentation. Wiley, New York; 2006, pp366-383.

74)Khang G, Kim SH, Kim MS, Lee HB: Hybrid, Composite, and Complex Biomaterials for Scaffolds. In: Principles of Regenerative Medicine. (eds. Lanza R, Atala A, Nerem R, Thomson W), Academic Press, New York; 2008, pp636-655.

75) Handbook of Intelligent Scaffold for Tissue Engineering \& Regenerative Medicine. (ed. Khang G), Pan Stanford Pub, New York; 2012.

76) Khang G, Kim SH, Rhee JM, Sha'ban M, Idrus RBH: Chap 8. Synthetic/natural hybrid scaffold for cartilage and disc regeneration. In: Biomaterials in Asia. World Scientific Pub, Singapore; 2008, pp207-221.

77)Khang G: Importance of inflammation reaction of scaffold for the application of regenerative medicine. Inflamm Regene. 2012; 35: 178-187. 